\title{
Phytoplankton community in a large shallow eutrophic lake (Lake Dianchi, Southwest China)
}

Chun-li ZHOU

1State Key Laboratory of Freshwater Ecology and Biotechnology, Institute of Hydrobiology, C A S, Wuhan, Hubei 430072, P. R. China

2 Graduate School of Chinese Academy of Sciences, Beijing, 100049 P. R. China

\section{ABSTRACT}

Monthly investigation is executed during April 2006 to May 2007, focusing on the abundance and composition of phytoplankton in a large $\left(300 \mathrm{~km}^{2}\right)$ shallow ( mean depth $4.4 \mathrm{~m}$ ) eutrophic lake ( Lake Dianchi ).

The presence of phytoplankton in northern bay was the highest, while that in the southern part the lowest, and center part and northern part conditions represented an intermediate state between these two. Phytoplankton communities dominated by cyanobacteria, and Microcystis bloom occurred in the whole year. Annual average phytoplankton cell number was $8.7 \times 10^{7}$ cells $\mathrm{L}^{-1}$, of which $93.6 \%$ was Microcystis, $4.5 \%$ were Chlorophyta and $0.3 \%$ was Aphanizomenon.

Comparative studies of our investigation against conditions in the past indicate that phytoplankton abundance and diversity decreased and cell miniaturization occurs in 2006 2007.

Key words: Lake Dianchi, lake, phytoplankton, bloom -forming cyanobacteria, biomass, temporal and spatial variation

\section{INTRODUCTION}

Lake Dianchi is the sixth largest freshwater lake in China and the largest in Yunnan-Guizhou Plateau. It is called "bright pearl of Plateau". With multiple functions as aquatic farming, irrigation and water supply, tourism, shipping, climate regulation, etc., Lake Dianchi plays a key role on economy and social development in Kunming. Lake Dianchi is under special geography and climate conditions, such as

\section{Li-rong SONG}

1. State Key Laboratory of Freshwater Ecology and Biotechnology, Institute of Hydrobiology, C A S, Wuhan, Hubei 430072, P. R. China

Correspondence should be addressed to (lrsong@ihb.ac.cn, zhouchli@163.com)

location in the lowest part of Kunming Basin, small watershed area, indigent of water resources, lack of transit water recharge, concentrated waterfall in its watershed, mild climate, long sunshine time, large evaporation amount and so on. However, since 1990s, with the expanding of city and enhancing of urbanization, eco-environmental stress becomes more drastic and the ecological problem of water-pollution and eutrophication gradually stands out.

To investigate the abundance and composition of phytoplankton in Lake Dianchi and to provide scientific basis for water-bloom pollution treatment and control, monthly investigation and research on 15 sampling sites in Lake Dianchi was executed during April 2006 to May 2007.

\section{METHODS}

\subsection{Sampling}

According to cases-clustering method used to cluster 7 biotic indexes obtained in April 2006, combining with distinctiveness of water bloom in different lake areas, Lake Dianchi was divided into 4 following research parts: PART I (1-6), PART II(7-10), PART III(11-14) and PART IV (15 listed out alone).(see Table 1)

Phytoplankton samples were collected and data was obtained based on norms ${ }^{[1][2][3][4]}$. 


\section{RESULTS}

3.1.Species richness and surface abundance of phytoplankton

A total number of 185 phytoplankton taxa (including Bacillariophyta21, Chlorophyta85, Chrysophyta5, Cryptophyta2, Cyanobacteria58, Euglenophyta7, Pyrrophyta3, and Xanthophyta 4 were encountered in the water samples during the period of study (See Table 1). Taxa number exceeds 106 that reported in 2001-2001 [5] [6] [ 7], but Xanthophyta and Chrysophyta are found again. The community was dominated by cyanobacteria. Cyanobacteria exceeded the others almost 11 months during the whole year. In cyanobacteria, Microcystis increased while Aphanizomenon decreased compared with that in 2002.

Phytoplankton communities dominated by cyanobacteria, and Microcystis bloom occurred in the whole year, annual average phytoplankton cell number was $8.7 \mathrm{x}$ $10^{7}$ cells $\mathrm{L}^{-1}$, of which $93.6 \%$ were Microcystis, $4.5 \%$ were Chlorophyta and $0.3 \%$ were Aphanizomenon (See Table 2).

Most species still are from Chlorophyta, there are 85 taxa in Lake Dianchi. Compared with the prior research in 2001-2002(Li Yuan), the dominance of Microcystis water blooms in all the several sites of PART I with large area in March, just before Aphanizomenon flos-aquae bloomed in large scale, while euglena can caused water blooms in Lake Dianchi continue longer than 10 months in a year; the highest cell density of water bloom even reach $10^{9}$ units/L; dominant species Aphanizomenon flos-aquae (early spring ) and Microcystis (summer\& autumn) in water booms success as reported before.

The dominant species in 50s, Chlorophyta and dinoflagellate, are replaced by Chlorophyta, Bacillariaphyta and Cyanobacteria at the 80 s. In 80 s both Bacillariophyta and Cyanobacteria are dominant but in 90s Cyanobacteria exceed the others. In 90s, Cyanobacteria dominate, of which most of them are filamentous Planktothrix, Aphanizomenon and colonial Microcystis. In the beginning of 21 century, the dominance of Planktothrix and Aphanizomenon are weakened but colonial Microcystis dominate. Dominant phytoplankton species change rather rapid. This reflects that the water quality of Lake Dianchi is worsening under affluences of human activities.

\subsection{Spatial variation of cell density phytoplankton}

From the spatial variation of the percentage of the bloom-forming cyanobacteria, the presence of Microcystis in Part IV was the highest and that in PART I was the lowest but conditions of PART II and PART III represented an intermediate state between these two.

The temporal variation of the Phytoplankton community total wet weight, the biomass of bloom-forming cyanobacteria is accorded with Microcystis on the temporal variation, which is higher in summer and winter but lower in spring and winter. The presence of Microcystis in North bay was the highest and that in the South part was the lowest, but conditions of center part and north part represented an intermediate state between these two. The dominant, Microcystis population started growing rapidly with maximum abundance in late April, contributing significantly to the summer peak in phytoplankton biomass, while Chlorophyta and some other Algae contributing significantly to Spring Phytoplankton biomass. From March to May Aphanizomenon were highly productive in entire lake, and at at period of time, its population was the highest. In April and May, Chlorophyta and other alegae like Euglenophyta and Pyrrophyta blooms, owing to their larger individuals, they take up $80 \%$ wet weight of phytoplankton.

\section{DISCUSSIONS}

Other abundant algae in Lake Dianchi (in spring) were Ceratium hirundinella (dinoflagellate, Nitzschia closterium, Hormidium sp. (Chlorophyta), Euglena spp.( euglena).

From the spatial variation of the percentage of the bloom-forming cyanobacteria, the presence of Microcystis in Part IV was the highest and that in PART I was the lowest but PART II and PART III conditions represented an intermediate state between these two.

Comparative studies on our investigation and its conditions in the past sixty years, it suggested that phytoplankton Abundance and Diversity decreased and cell miniaturization occurs. So it is really a long-term and 
arduous task to control pollution and recover the ecosystem system.

\section{ACKNOWLEDGEMENTS}

Special thanks to Professor Bang-ding Xiao, and Doc. Jie Li, Doc. Neng Wan etc., for their kind help on sampling. This work was supported by 863 Program of the Ministry of Science and Technology (2005AA60101005) and Chinese Academy of Sciences Project (KZCX2-YW-426).

\section{REFERENCES}

[1] Skuja H . Algae. Handel - Mazzetti H. Symbolae sinicae . wien: Julius Springer.1937.

[2] LI Liang-ehing. 1939. Freshwater algae of Yunnan expedium.1935-1937. Part I.I bid, 1938, 9 (1):31-57.

[3] LI Liang-ehing. 1939. Freshwater algae of Yunnan expedium. 1935-1937. Part II . I bid, 1938, 9 (4): 207-244.

[4] Desikachary T V. Cyanophyta. New Delhi: Indian Council of Agriculture Research, 1959. 81- 132 .

[5] ZHANG Mei, LI Yuan, WANG Ruo-nan. The research of biodiversity for the species of phytoplankton in Dianchi Lake, Kunming, China. Journal of Yunnan University. 2005,27(2) : $170-175$

[6] LI Yuan, ZHANG Mei, WANG Ruo-nan 2005 The temporal and spation variation of the cyanobacteria hich caused the water bloom in the Dianchi Lake, Kunming China 27(3):272-276

[7] ZHANG Mei, LI Yuan, WANG Ruo-nan. Dynamic variation for the species of phytoplankton in Dianchi Lake,China 2006 28(1):73-77

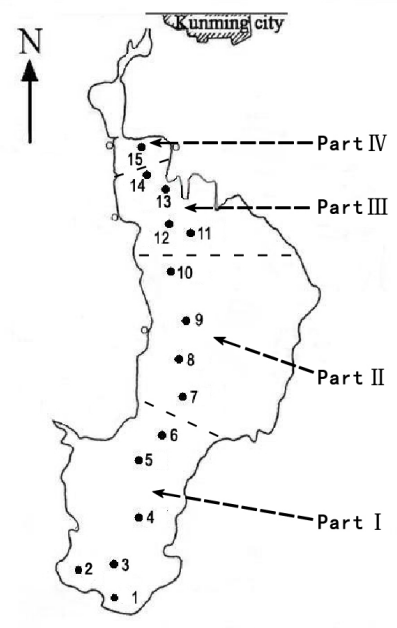

FIGURE 1. SKETCH MAP OF THE SAMPLING SITES IN LAKD DIANCHI

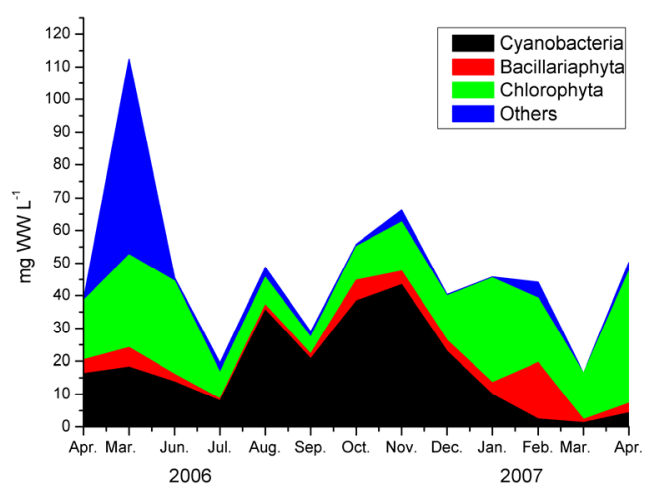

FIGURE 2. TEMPERAL VARIATION OF THE AVERAGE PHYTOPLANKTON WET WEIGHT 
TABLE 1.THE COMMUNITY STRUCTURE OF PHYTOPLANKTON IN LAKE DIANCHI

\begin{tabular}{lccc}
\hline & Qty. of families & Qty. of genera & Qty. of species \\
\hline Bacillariophyta & 7 & 16 & 21 \\
Chlorophyta & 16 & 40 & 85 \\
Chrysophyta & 3 & 4 & 5 \\
Cryptophyta & 1 & 2 & 2 \\
Cyanobacteria & 8 & 18 & 58 \\
Euglenophyta & 1 & 3 & 7 \\
Pyrrophyta & 3 & 3 & 3 \\
Xanthophyta & 3 & 3 & 4 \\
Total & 42 & 89 & 185 \\
\hline
\end{tabular}

TABle 2. SPATIAL VARIATION OF THE PERCENTAGE OF PHytoplankTON $\left(\times 10^{5} \mathrm{CELL} / \mathrm{L}\right)$

\begin{tabular}{llllll}
\hline & Part I & Part II & Part III & Part IV & MEAN \\
\hline Microcystis & 557.3 & 827.8 & 900.6 & 985.3 & 817.7 \\
Aphanizomenon & 1.2 & 1.0 & 1.7 & 1.1 & 1.2 \\
Cyanobacteria & 565.9 & 834.4 & 908.8 & 994.3 & 825.9 \\
Bacillariaphyta & 6.7 & 6.3 & 11 & 6.9 & 7.7 \\
Chlorophyta & 45.3 & 42.4 & 46.5 & 24.0 & 39.6 \\
Others & 0.4 & 0.2 & 0.4 & 0.4 & 0.3 \\
Total & 618.3 & 883.3 & 966.7 & 1025.6 & 873.5 \\
\hline
\end{tabular}

